\title{
„Otrzymała od Ducha Świętego wielki charyzmat”: św. Urszula Ledóchowska i Urszulanki Serca Jezusa Konającego, Uniwersytet Papieski Jana Pawła II, Wydawnictwo Naukowe, Kraków 2012
}

Życie konsekrowane od samego początku życia Kościoła stanowi o jego duchowej kondycji. Wielość charyzmatów zakonnych jest potwierdzeniem nieustannie działającego w nim Ducha Świętego. Osoby konsekrowane, które są powołane w pierwszym rzędzie do kontemplacji oblicza Chrystusa ukrzyżowanego i chwalebnego, świadczą w świecie o Jego miłości. Patrząc zaś na życie ludzi świętych, założycieli instytutów życia konsekrowanego, widzimy, że Duch Święty nieustannie działa w historii i może wydobyć z ludzkich dramatów takie rozeznanie wydarzeń, które przyczynia się do otwarcia tajemnicy miłosierdzia i szerzenia pokoju pomiędzy ludźmi. W instrukcji Rozpoczać na nowo od Chrystusa czytamy: „Duch Święty bowiem w zamęcie panującym w narodach pobudzaw wielu tęsknotę zainnym światem, który jest już obecny między nami" (RdCh 1 ). W tym kontekście sytuuje się postać i dzieło św. Urszuli Ledóchowskiej, założycielki Zgromadzenia Sióstr Urszulanek Serca Jezusa Konającego.

Z wielką radością należy przyjąć na rynku wydawniczym nową publikację pt. „Otrzymała od Ducha Świętego wielki charyzmat": św. Urszula Ledóchowska i Urszulanki Serca Jezusa Konającego.
Prezentowana książka jest próbą ukazaniaśw. Urszuli Ledóchowskiej jako „niezwykłej w swojej zwykłości” kobiety, która w pełni odpowiedziała na słowo Boże, wykorzystując wszystkie talenty otrzymane od Stwórcy. Jej postać ukazuje nam - współczesnym, że wierna współpraca z łaską Bożą może zaowocować dziełami, których po ludzku nie da się zrozumieć ani wytłumaczyć. Bezgraniczne zaufanie wobec Boga sprawiło, że św. Urszula Ledóchowska stała się ewangelicznym zaczynem nowego dzieła, które dziś nie traci na swej aktualności, wręcz przeciwnie - staje się wyzwaniem współczesnych czasów.

Recenzowana książka ukazuje się w serii wydawniczej Duchowość Klasztorów Polskich: Przekaz i Komunikacja pod redakcją ks. W. Misztala.

Omawiana pozycja jest szerokim komentarzem do słów Jana Pawła II: „Otrzymała od Ducha Świętego wielki charyzmat”, które wypowiedział podczas swojej wizyty w Domu Generalnym Zgromadzenia Sióstr Urszulanek Serca Jezusa Konającego w Rzymie 26 stycznia 1986 roku.

Całość opracowania składa się z 10 artykułów tematycznych ukazujących bogactwo życia, duchowości i świętości Urszuli Ledóchowskiej oraz 
dzieło jej duchowych córek - Sióstr Urszulanek Serca Jezusa Konającego. Szerokość omawianych zagadnień daje czytelnikowi pewną syntezę charyzmatu świętej i pokazuje jego kontynuację w czasach współczesnych.

Patrząc na strukturę książki, można dostrzec w życiu Urszuli Ledóchowskiej pewną stopniowość odczytywania powołania do służby Bożej, jego realizację i duchowe przesłanie, które jest nieustannie aktualizowane w czasach współczesnych. Całość opracowania poprzedzona jest słowem wprowadzenia Redaktora serii Duchowość Klasztorów Polskich: Przekaz i Komunikacja - ks. W. Misztala. Ukazuje on aktualność przesłania pozostawionego przez św. Urszulę Ledóchowską. Potrafiła ona bowiem wzbić się ponad wszelkie podziały społeczno-kulturowo-religijne i wskazywać na to, co jest najważniejsze: człowiek jest obrazem i podobieństwem samego Boga.

M. Franciszka Sagun, przełożona generalna Zgromadzenia Sióstr Urszulanek Serca Jezusa Konającego, we wstępie do opracowania wskazuje na zasadność powstałego dzieła. Zaznacza, że jest czymś wartościowym i pożytecznym, gdy na nowo próbuje się odczytać spuściznę duchową Założycielki w kontekście współczesności. W ten sposób powstała pozycja książkowa jest okazją do kolejnego pochylenia się nad postacią św. Urszuli Ledóchowskiej i wydobycia tego, co dziś wydaje się aktualne dla ludzi żyjących w XXI wieku.

Po tak nakreślonym wstępie, abp W. Ziółek w artykule pt. Aktualność duchowości i charyzmatu św. Urszuli i Urszulanek SJK w obecnej rzeczywistości społecznej i religijnej ukazuje głębię duchowości i charyzmatuśw. Urszuli.W rozważaniu tym ksiądz biskup zwraca szczególną uwagę na cnotę wiary świętej, którą porównuje do wiary Abrahama. Ponadto zaznacza, że źródłem jej apostolatu była Eucharystia, którą przeżywała jako sakrament miłości i ofiary (s. 18). Doświadczenie miłości Jezusa sprawiało, że św. Urszula nie mogła zatrzymać jej dla siebie. W ten sposób uczy ona współczesnego człowieka, jak budować świat, w którym miłość do Boga i człowieka stanowią centrum życia.

Kolejny artykuł, autorstwa s. Małgorzaty Krupeckiej, został poświęcony jubileuszowi
90 lat obecności Sióstr Urszulanek Serca Jezusa Konającego w Łodzi i Kościele łódzkim. Autorka podkreśla tu niezwykłość dynamizmu nowo powstałego zgromadzenia, które rozpoczęło swoją działalnośćw dwudziestoleciu międzywojennymna prośbę pierwszego biskupa tej diecezjiWincentego Tymienieckiego. Apostolat sióstr Urszulanek SJK to odpowiedź na ówczesne wyzwania epoki, do których należały: katechizacja, opieka nad ubogimi, troska o rodzinę, zwłaszcza o godność kobiety. Autorka opisuje szczegółowo początki działalności sióstr naznaczone dramatem wojny. Pomimo trudności związanych z koniecznością opuszczenia niektórych placówek, Zgromadzenie nie zaprzestało swej posługi. Powstawały tzw. tymczasowe placówki wojenne i przyjmowano do Zgromadzenia nowe osoby. Czas powojenny przyniósł zmianę nastawienia władz państwowych do wspólnot zakonnych, co spowodowało, iż konieczna była reorganizacja ich życia. Pomimo to, żywotność charyzmatu Zgromadzenia potwierdzana była i jest nieustannie podejmowanymi inicjatywami wśród ludzi najbardziej potrzebujących.

Z kolei bp Adam Lepa uwydatnia obecność mediów jako narzędzia ewangelizacji w ujęciu św. Urszuli Ledóchowskiej. Wskazując na współczesny obraz mediów oraz związaną z nimi przestrzeń manipulacji, podkreśla pozytywną wartość środków społecznego przekazu w dziele ewangelizacji. W tym zakresie św. Urszula Ledóchowska swoje plany ewangelizacyjne wiązała przede wszystkim ze słowem drukowanym. Powołała do życia pisma, które adresowane były zarówno dla młodych, jak i starszych osób. Miały one charakter formacyjny.

Apostolat rozwijany przez słowo drukowane, który stał się ważnym elementem realizacji charyzmatu świętej, podejmował najważniejsze problemy odrodzonej ojczyzny (s. 75). Bp A. Lepa, omawiając ten rodzaj apostolatu, wskazuje na niezwykłe wyczucie znaków czasu, które towarzyszyło św. Urszuli Ledóchowskiej.

Na szczególną uwagę zasługuje rozmowa $\mathrm{z}$ matką Jolantą Olech pt. Stare i nowe w stylu życia konsekrowanego św. Urszuli i szarych Urszulanek. Matka Jolanta określa św. Urszulę mianem kobiety zasłuchanej w Pana Boga, starającej się 
wypełnić Jego wolę w codzienności (s. 84). Ta postawa czyniła ją otwartą na potrzeby epoki, w której żyła. Rozmówczyni ukazuje Założycielkę swojego Zgromadzenia jako osobę niezwykłego dynamizmu i otwartości na potrzeby drugich. Przedstawia zatem św. Urszulę jako tę, która nie czekała, aż ludzie sami do niej przyjdą, ale jako pierwsza wychodziła do nich z „ewangelicznym pośpiechem”. Potrafiła łączyć to, co określa się mianem „zdrowej tradycji”, z tym, co określa się pojęciem „nowość”. Motywacją wszelkich działań była miłość do Tego, który ją powołał i nieustannie posyłał w nowe, czasami nieznane obszary ludzkiego życia.

Artykuł autorstwa ks. W. Zyzaka pt. Kontemplacja krzyża jako centrum duchowości świętej Urszuli Ledóchowskiej stanowi niejako kompendium duchowości pasyjnej św. Urszuli. Autor podkreśla szczególne miejsce kontemplacji krzyża w życiu duchowym samej świętej, jak i w duchowości całego Zgromadzenia Sióstr Serca Jezusa Konającego (s. 94). Ważne miejsce zajmuje w niej modlitwa i życie sakramentalne. Ks. W. Zyzak próbuje ukazać to, co najbardziej osobiste a zarazem bolesne w życiu duchowym św. Urszuli Ledóchowskiej. Można pokusić się o stwierdzenie, że zagadnienia podejmowane przez autora są niezwykle cenne dla zrozumienia całej duchowości świętej i jej osobistego charyzmatu. Kontemplacja Serca Jezusa konającego staje się źródłem apostolatu św. Urszuli oraz jej duchowych córek. Autor wskazuje ponadto na obecność duchowości maryjnej, która jest ściśle związana z duchowością pasyjną.

R. Paluch w artykule pt. Pragnienie świętości $u$ św. Urszuli Ledóchowskiej ukazuje świętą jako osobę całkowicie oddaną sprawom Bożym. Jej pragnienie świętości zaliczone zostaje do „skarbca Kościoła". Stanowi o jego przeszłości i jest nadzieją na przyszłość (s. 127). Autor podkreśla aktualność duchowego przesłania św. Urszuli, zwracając uwagę na jej żywe świadectwo wiary, na zgodność tego, co święta pisała, z tym, czym żyła na co dzień. Św. Urszula, realizując ideał świętości, swoją osobistą postawą zaszczepiała w spotykanych przez nią osobach wartości, którymi sama żyła. Ważne w omawianym artykule jest ukazanie przestrzeni świętości, w której wzrastała św. Urszula Ledóchowska. Przestrzeń tę tworzyła przede wszystkim jej rodzina (s.139). Potwierdzeniem realizacji ideału świętości przez św. Urszulę było bezwarunkowe posłuszeństwo Kościołowi. Z woli Kościoła czuła się posłana i w Kościele szukała właściwych sposobów ewangelizacji.

Ewangelia $w$ duchowości św. Urszuli to tytuł kolejnego artykułu autorstwa ks. W. Misztala. Autor koncentruje się tu m.in. na obecności słowa Bożego w osobistym życiu duchowym św. Urszuli oraz jego „komuniostwórczym” działaniu.Św. Urszula widziała w Ewangelii - jak zaznacza autor - podstawę osobistej duchowości oraz duchowości całego Zgromadzenia. Dlatego święta pragnęła dzielić się z innymi owocami spotkania Boga w Piśmie Świętym (s. 170). Ks. W. Misztal wskazuje na praktyczność zastosowania słowa Bożego przez św. Urszulę w życiu codziennym. Miłość do słowa Bożego stała się siłą jednoczącą - bo słowo Boże było dla niej żywe i skuteczne. Słowo Boże tak rozumiane i przyjmowane sprawiało, żeświęta stała się prawdziwym współpracownikiem Boga i narzędziem w ewangelizacji świata. Często podkreślała, że spotkanie ze słowem Bożym musi być owocne, a jeśli nie jest, należy uważać je za zmarnowane (s. 183). Tworząc komunię z Bogiem, dzięki Jego Słowu człowiek jest bowiem w stanie tworzyć komunię z innymi.

W kolejnym artykule ks. P. Gabary koncentruje swą refleksję na temacie: Źródła i formy aktualnej, twórczej i skutecznej działalności ewangelizacyjnej św. Urszuli. Autor zwraca uwagę na kształtowanie postawy apostolskiej św. Urszuli Ledóchowskiej już w domu rodzinnym (s. 197). Ewangeliczny przykład rodziców tworzył klimat dla wszechstronnego, a zarazem roztropnego patrzenia na świat. Dom rodzinny wywarł ogromny wpływ na późniejsze życie świętej. W dalszej części artykułu ks. P. Gabara zwraca uwagę czytelnika na przestrzeń apostolatu św. Urszuli. Ukazuje świętą jako apostołkę swoich czasów. Niezwykle ważne w życiu św. Urszuli było otwarcie na wyzwania nowej epoki. Choć nie należała do intelektualistek, doskonale po- 
trafiła orientować się w potrzebach drugiego człowieka. Miała świadomość, że miłość chrześcijańska winna objąć każdego człowieka i że to Bóg w ostateczności wyznacza sposób działania apostolskiego (s. 218). Stąd też święta zapraszała do współpracy wszystkie osoby dobrej woli, niezależnie od wyznania. W końcowej części artykułu zostaje podjęty problem aktualności działań apostolskich św. Urszuli wobec wyzwań nowej ewangelizacji.

Następny artykuł, zatytułowany:Kościół w dialogu zeświatem, autorstwa ks. G. Dziewulskiego, ukazuje niezwykłe, jak na owe czasy, zaangażowanie św. Urszuli w dziedzinie współpracy ekumenicznej, edukacyjno-wychowawczej oraz relacji i współpracy z nie-chrześcijanami (s. 234). Święta zostaje ukazana jako osoba bardzo mocno zakorzeniona w miłości do Kościoła i pragnąca przyprowadzić do niego innych. W jej postawie zostaje ukazany wielki szacunek dla innych wyznań. Ks. G. Dziewulski ukazuje św. Urszulę Ledóchowską jako osobę dialogu, zatroskaną o dobro duchowe każdego człowieka. Święta wykorzystywała do tego wszystkie dostępne na owe czasy formy komunikacji międzyludzkiej. Boleśnie przeżywała sytuacje, w których doznawała braku dobrej woli ze strony hierarchii (np. zakazużywaniajęzyka rosyjskiego w kaplicy sióstr wydany przez arcybiskupa mohylewskiego, który to zakaz spowodował, że wielu Rosjan odeszło z Kościoła katolickiego do Kościoła prawosławego). Wszystko to sprawiało, że dla świętej priorytetem była troska o dobro bliźniego, był on bowiem dla niej zawsze wielkim darem, ale i zadaniem na całe życie.

Ostatni artykuł, autorstwa ks. H. Wejmana, pt. Ubodzy w sercu posłannictwa św. Urszuli i jej duchowych córek koncentruje uwagę czytelnika na środowisku posługi świętej i zgromadzenia zakonnego, którego była matką i założycielką. Autor wskazuje na źródło postawy ubóstwa świętej. Tym źródłem była osobowa więź z Jezusem Chrystusem. Następnie podejmuje zagadnienie ubóstwa duchowego i materialnego. Ważną przestrzenią działalności apostolskiej św. Urszuli i jej duchowych córek były osoby ubogie materialnie. Wśród nich święta wskazuje na osoby biedne inte- lektualnie i duchowo(s. 279). By ustrzec człowieka przed złymi skłonnościami, św. Urszula kładła nacisk na konieczność rozbudzania wrażliwości na Boga w okresie dzieciństwa. Jako środki duchowe zalecała modlitwę, życie sakramentalne, rachunek sumienia i nieustanną pracę nad sobą (s. 285). Autor zaznacza, że wielość podejmowanych inicjatyw apostolskich była odpowiedzią na oczekiwania jej współczesnych. Św. Urszula potrafiła wspaniale odczytywać znaki czasu i odpowiadać na nie w świetle nauki Chrystusa. W końcowej części artykułu zostaje ukazana kontynuacja misji świętej przez jej córki duchowe - Siostry Urszulanki Serca Jezusa Konającego.

W zakresie omawianych zagadnień należy podkreślić kompetencje autorów wspomnianych artykułów. Każdy z nich przeprowadził refleksję w wyznaczonym temacie w sposób systematyczny i metodyczny. Wielość specjalizacji teologicznych reprezentowanych przez autorów artykułów wskazuje na różnorodność podejść do omawianych zagadnień. Całość opracowania zyskuje także na różnorodności środowisk teologicznych, jakie są przez nich reprezentowane. Mamy tu na uwadze środowiska: krakowskie, łódzkie, szczecińskie oraz środowisko samych Sióstr Urszulanek Serca Konającego Jezusa - duchowych córek św. Urszuli Ledóchowskiej.

Należy podkreślić dużą wnikliwość poszczególnych autorów w zakresie omawianych zagadnień. Potwierdzeniem tego jest obszerna bibliografia zawarta w przypisach. Widoczny jest także wysiłek redakcyjny, który polegał przede wszystkim na tym, by poszczególne artykuły ukazały różnorodność życia, duchowości i apostolatu św. Urszuli oraz jej córek duchowych, przy zachowaniu ram nakreślonych tematem pozycji: „Otrzymała od Ducha Świętego wielki charyzmat": św. Urszula Ledóchowska i Urszulanki Serca Jezusa Konajacego.

Pod względem staranności tekstu prezentowana publikacja nie budzi jakichkolwiek wątpliwości. Jest to książka dobrze przygotowana, poparta bogatą literaturą uwzględniającą treści zawarte w Piśmie Świętym i współczesnym nauczaniu Kościoła. W artykułach wykorzystano duchowy dorobek św. Urszuli Ledóchowskiej, 
wypowiedzi bł. Jana Pawła II oraz opracowania dotyczące omawianej tematyki. Wszystko to zasługuje w pełni nauznanie i szacunek wobec tych, którzy podjęli się redakcji całości opracowania.

W ocenie merytorycznej należy podkreślić fachowość i kompetentność tych, którzy podjęli się trudu ukazania charyzmatu św. Urszuli Ledóchowskiej oraz spadkobierczyń jej duchowego przesłania - Sióstr Urszulanek Serca Jezusa
Konającego. Należy mieć nadzieję, że recenzowana książka przyczyni się do szerszego spojrzenia na postać św. Urszuli Ledóchowskiej i stanie się przyczynkiem do dalszych refleksji w zakresie podejmowanych tematów. $Z$ pewnością pozycja ta stanowi ważne dzieło dla środowiska teologów, zwłaszcza teologów duchowości.

Jacek Kiciński CMF 